\title{
PERCEPTION OF ODD PRICES IN A POST-SOVIET COUNTRY: AN IMPACT OF THE IDEOLOGY OF PLANNED ECONOMY
}

\author{
Vytautas Dikcius $^{1}$, Kristina Katkuviene ${ }^{2}$ \\ International Business School, Vilnius University, Sauletekio al. 22, Vilnius, Lithuania \\ E-mails: ${ }^{1}$ v.dikcius@gmail.com (corresponding author); ${ }^{2}$ kristina@fesla.lt \\ Received 08 April 2013; accepted 07 August 2013
}

\begin{abstract}
This empirical paper analyzes the perception of odd prices in a Post-Soviet country. Two different streams of perception of odd prices are developed - a level effect and an image effect. The paper focuses on the latter effect. The authors analyze the perception of odd prices in different categories of products - convenience goods, clothes and domestic appliances. In addition, four different levels of a price were used in order to measure the perception of a price having various price levels. The results showed that Lithuanians have a different attitude about odd prices compared with the research in developed countries. At the same time the survey showed that the respondents' experience related to odd prices fits the results of the research from developed countries. Moreover, the participants of the survey intuitively perceived odd prices as something negative and associated odd prices with cheating in the case of convenience products, or with discounted products in the case of shopping goods. This research demonstrates that companies should not practice nine-ending pricing widely since the respondents associated odd prices were preferred more in the case of cheap products (up to 10 LTL) than expensive products, and odd prices were related with discounted products in the case of shopping goods.
\end{abstract}

Keywords: odd prices, price perception, emerging economies, Post-Soviet countries, image effects, consumer behavior, convenience goods, shopping goods.

Reference to this paper should be made as follows: Dikcius, V.; Katkuviene, K. 2014. Perception of odd prices in a Post-Soviet country: an impact of the ideology of planned economy, Journal of Business Economics and Management 15(2): 356-368.

JEL Classification: M30, M31.

\section{Introduction}

A price was, is and will be one of the most important criteria which influences consumers' purchasing decisions. This is common to different countries, because the market economy cannot exist without prices. A profit is the main goal of pricing for a number of companies. However, pricing is an important activity when the companies going to win a bigger part of a market react to actions of competitors, in survival or image development. Obviously, companies expect a corresponding consumer's reaction to their pricing. Unfortunately, sometimes consumers react differently to a company's pricing activities. Consumers perceive a price subjectively, depending on their experience with 
a certain product. In some cases they compare the current price with the prices in the past or with the prices which they remember or even imagine. Finally, the perception of a price depends on the purpose of purchasing or importance of a product in a certain situation. Due to a variety of consumers companies developed different strategies of pricing (Snieškienė 2009).

One of such strategies is an odd price. Odd prices are sometimes referred to as psychological prices (Schindler, Warren 1988), magic prices, charm prices, irrational prices, intuitive prices or rule-of-thumb prices (Folkertsma 2002; Gendall et al. 1997), as well as odd prices or prices which end with number 9 (Guido, Peluso 2004). Wagner and Beinke (2006) separate two types of odd prices - odd-odd prices (29.99 or 29.95) because they are just below the line 30.00 and simple odd prices as 30.99 or 30.95 . However, their general characteristic is that they are set just below the nearest round figure for example, 9.99 instead of 10.00 (Gendall et al. 1997).

Evidence of odd pricing can be traced back more than 100 years (Schindler, Wiman 1989). One of the explanations for the introduction of odd pricing is that it arose as a measure to help combat theft by employees (Högl 1988). Odd prices were adopted to force salespeople to issue change and thereby make it difficult for them to pocket the customer's payment without recording a sale (Gendall et al. 1997). Nowadays usage of odd prices is based on one of the underlying assumptions which encourages retailers to apply those prices so that consumers may consider odd prices as lower and these prices can have positive effects on sales (Ngobo et al. 2010).

Prior researches reported an intense practice of this method, with the percentage of prices ending in the digit 9 ranging between 52\% and 80\% (Mace 2012). Suri et al. (2004) point that odd prices dominate in various areas of trade, across different products. However, Suri, Anderson and Kotlov (2004) mentioned that the studies related to odd prices were done mainly in the USA or other developed countries. Schindler (2009) noticed intensive use of odd price in the USA and other English-speaking countries. Wagner and Beinke (2006) added that even though odd prices are noticeable in different countries, they are more popular in western countries. Nguyen et al. (2007) agree that perception of odd prices could be not the same in different markets. They noticed that odd prices create an effect of cheapness more often in low context countries (for example, western cultures) than high context countries. A research performed by Hooley et al. (2000) proved that pricing strategies used in Central European countries (postsoviet countries) were not clear. The reason for that was Eastern European countries being under an impact of the Soviet ideology, which says that a price is an amount of money paid for a product. Moreover, there was no need for competition and ability to sell more products since companies worked in the planned economy and a shortage of goods was obvious. According to Usunier (1996), 50 years of the Soviet ideology and the planned economy created a cultural heritage, which caused specific perception of marketing strategies brought from Western Europe and the USA (Usunier 1996). Asamoah and Chovancova (2011) noticed that Czech consumers preferred odd prices compared with other endings of a price. However, the authors explain the reason for such preference was due to the fact that odd prices were used very often by retailers and 
such pricing strategy became a norm (Asamoah, Chovancova 2011). Lithuania was a part of the Soviet Union in contrast to Czech and Poland which were just a part of the block of Soviet countries and remained independent countries. A stronger impact of the ideology of planned economy and 15 years of usage of odd prices by retailers provide a strong background to believe that Lithuanian consumers perceive odd price differently than the literature suggests. The aim of this paper to understand Lithuanians' attitudes toward odd prices and check their correspondence to those presented in the literature.

\section{Theoretical background}

\subsection{Perception of odd prices - level effects}

Previous researches showed that odd prices might have a positive impact on sales. The authors (G. A. Brenner, R. Brenner 1982; Holdershaw et al. 1997; Lambert 1975; Nagle, Holden 1995; Naipaul, Parsa 2001; Quigley, Notarantonio 1992; Schindler 1984, 1991; Schindler, Kibarian 1993, 2001; Schindler, Kirby 1997; Schindler, Wiman 1989; Stiving, Winer 1997) analyzed how odd prices impacted cognitive processes related to the information of a price and how these processes should increase the curve of demand. Guido and Pelluso (2004) say that an effect of the right number exists only due to consumers' interpretation. Stiving and Winer (1997) split these cognitive processes into two categories: level effects and image effects. Level effects explain how odd prices can lead consumers to underestimating prices during perception and/or retrieval of price information from a memory (Guido, Peluso 2004; Gaston-Breton 2011). The original and most common explanation is related to underestimation of a price. Consumers tend to round these prices to down during perception (Alpert et al. 1984; Lambert 1975; Schindler 1984; Schindler, Warren 1988). Another explanation is related to the fact that consumers compare prices from left to right comparing two numbers among themselves (Monroe 1973). Some authors call such effect a left numbers effect (Thomas, Morwitz 2005; Basu 2006). Stiving and Winer (1997) argued that left numbers had bigger impact on perception of a price than right numbers. Liang and Kanetkar (2006) noticed that consumers did not evaluate a price as one number, but they understand a price as a set of numbers and evaluated each number separately. The third factor which explains level effects is related to the limited memory capacity of human beings and limited ability to remember numbers of a price. G. A. Brenner and R. Brenner (1982) say that as consumers are exposed to continuous information on a price they only store the most valuable message which they perceive as the first digits of a number. Finally, the concept of accessibility is important because if a mental representation comes to mind more easily, then the representation is likely to be used in thought more frequently. Studies that require respondents to generate numbers clearly point to 0-ending numbers as having greater cognitive accessibility (Hornik et al. 1994; Hultsman et al. 1989). It means consumers store even prices in their memory. Therefore, trying to compare a new odd price with existing one in a memory, consumers perceive an odd price as smaller (Schindler, Kirby 1997; Boyes et al. 2007). 


\subsection{Perception of odd prices - image effects}

Odd prices are related to image effects as well. Image effect explains how consumers perceive meaning through the rightmost digits of a price. This effect is related to an image of the price or to an image of the product. An image of the price indicates that products with odd prices will be perceived as cheaper. Bizer and Schindler (2005) state retailers who believe that consumers give insufficient consideration to the rightmost digits would view odd prices as a simple way to create lower-price perception. Talking about an image of the price, an odd price can be associated with a price discount. This effect can derive from the fact that consumers may tend to drop off, or give less attention to the rightmost digits of a price; thus, perceptually, they underestimate the level of an odd price (Schindler, Kibarian 1993). Quigley and Notarantonio (1992) argue that consumers who saw an advertisement with a 99 or 98 ending price were significantly more likely to judge the advertised product as "probably on sale" than were those who saw the same ad with a 00 ending. Schindler and Kibarian (2001) determined that when an item was displayed with a 99 ending price rather than 00 ending price, consumers were more likely to judge the item to be "on sale". Another effect of an image of the price is associated with a possibility to save money or buy a product for lower price. Since consumers perceive that it is possible to buy a necessary product for a very "good" price during sale promotions, thus an odd price, which usually is used during that time, will show for consumers which products will have a possibility to save money.

Ngobo, Legohérel and Gueguen (2010) agree that a price with ending 99 is very often used as sales promotion and due to that consumers may perceive an odd price as a way to save money. The following hypotheses were formulated to point out that odd prices communicate lower-price perception:

H1: products with odd prices will be perceived as discounted products.

H2: odd prices are associated with getting money back.

H3: odd prices are perceived as a mean for saving money.

Image effects are related to perception of the quality of products. Usually odd prices create an image of low quality of products. Such effect is created because odd prices are used in a discount store very often (Stiving 2000) or can be related to products on sale, when retailers sell products that are far from the best quality (Rao, Monroe 1988). According to Stiving (2000), a price is very often used as a criterion to evaluate the quality of a product. Therefore, retailers' efforts to show a product cheaper have a negative effect - a low price indicates a poor quality of the product for consumers. Baumgartner and Steiner (2007) argue that high quality of a product is more associated with even prices ( 00 ending) than with odd prices ( 99 ending). However, Fortin et al. (2008) didn't prove that odd prices were associated with lower quality of products. At the same time the authors agreed that their results differed from the previous research and they expected the reason for that was the sample profile in their research - the research was done among students, who were more price sensitive that other consumers. That enables us to formulate the next hypotheses:

H4: odd prices will be perceived as lower quality products. 
H5: odd prices will be associated with cheaper products rather than expensive.

As it was mentioned in the introduction, different countries have unequal experience of using odd prices. Consumers habituate to odd prices and evaluate them as ordinary actions if odd prices are used for a long time. Contrariwise, a new marketing tool as every innovation can cause distrust in odd pricing, due to insufficient experience of consumers.

H6: odd prices are associated with cheating.

Baumgartner and Steiner (2007) mentioned that consumers evaluate prices differently some of them like prices with endings 99, while others vote for a 00 . Kleinsasser and Wagner (2011) presented one of possible explanations - perception of a price depends of a consumer's involvement level. The authors specified that consumers with a high level of involvement will pay more attention to even prices while odd prices would be more suitable for consumers with a low level of involvement (Kleinsasser, Wagner 2011). Quester and Lim (2003) stated that two categories of products - convenience goods and shopping goods - usually have different level of involvement. Convenience goods are usually perceived as goods which require a low level of involvement. On the contrary, consumers spend more time when they consider purchasing shopping goods. With regard to the analyzed literature we developed the additional hypothesis.

H7: perception of odd prices is more suitable for convenience goods than for shopping goods.

Ngobo et al. (2010) argued that odd prices didn't increase sales of expensive goods while in the case of cheap products they noticed an increase in a number of clients. In addition to this, Mace (2012) says that a bigger amount of products with an odd price is purchased in shops whose clients have higher income per household. We can assume that a price level might be related to the perception of an odd price. Therefore we add one more the hypothesis:

H8: perception of odd prices decreases as price level increases.

\section{Research methodology}

The main objective of the research is to study how consumers perceive odd prices and evaluate the correspondence of our findings with those from developed countries. The study included three major categories of products: convenience goods (like food, nonalcoholic beverages, and toothpaste), clothes, and domestic appliances (representing shopping goods and a different level of price). In addition, we selected four different levels of a price - less than 10 LTL (approx. 3 EUR), 10-100 LTL (approx. 3-30 EUR), 100-1,000 LTL (approx. 30-300 EUR) and 1,000-10,000 LTL (approx. 300-3,000 EUR) in order to measure perception of a price at various levels of the price.

The instrument for the survey was developed by integrating literature on odd price perception. Statements were developed according to statements used by Coulter (2002), Gueguen and Legoherel (2004), Hunt and Keaveney (1994). The statements were as follows: "I think an odd price is suitable for goods with a price ...", "I prefer a product with a price 6.99 to that with a price of 7.01 (for convenience products), 69.99 to 
70.11 (for clothes), and 699.99 to 700.11 (for domestic appliances)", "I think that an odd price represents a product with a discount", "An odd price means getting change", "An odd price enables me to save money", "Products with an odd price are worse in quality", "I think that odd prices are used more for cheap products than for expensive ones in the same category of products", "I associate an odd price with cheating". All statements were measured on a five-point scale, ranging from 1 - "strongly disagree" to 5 - "strongly agree". The questionnaire included the typical demographic characteristics (gender, age and income).

Respondents were selected using a method of judgmental sampling, the survey was performed by sending the questionnaires by e-mail. 207 Lithuanians participated in the research. The respondents represented various groups by their personal income (see Table 1).

Table 1. Sample profile

\begin{tabular}{cccccc}
\hline Gender & Percent & Age (years) & Percent & Incomes (subjective judgement) & Percent \\
\hline Male & 34 & $18-29$ & 49.3 & Very low & 7.7 \\
\hline Female & 66 & $30-39$ & 38.2 & Low & 22.2 \\
\hline \multicolumn{7}{c}{ More than 39 } & 12.6 & Average & 30.9 \\
\hline & & & High & 31.4 \\
\hline & & & Very high & 7.7 \\
\hline
\end{tabular}

The sample included $66 \%$ of female and $34 \%$ of male respondents. Almost a half of the respondents were 18-29 years old and 38\% of the respondents 30-39 years old, which means that the sample represented quite young people, who had limited experience of Soviet ideology. Only $12 \%$ of respondents were 40 years old and older. Their income was measured subjectively, based on a five point scale from very low to very high. That was done because one can earn 5,000 LTL and have 4,000 LTL of liabilities for financial institutions while another has income of 2,000 LTL and can use it for his own needs. Almost $30 \%$ of respondents assigned themselves to people with low or very low income and the same part evaluated their income as average, while the balance part thought they were rich or very rich. Other demographic characteristics of the respondents were not considered.

\section{Research findings}

The respondents evaluated all the statements below average, which means that they didn't agree with the presented statements (see Table 2). The respondents stated that they did not associate an odd price with a discount, with lower quality of products, with getting change, or with cheating. According to them, an odd price is used for cheaper products as well as for expensive ones in the same category of products, but these prices did not let save money. Such results significantly differ from the findings of other research in developed countries. Therefore we can conclude that respondents do not have clear understanding of usage of odd prices. 
Table 2. Respondents' attitude about odd prices

\begin{tabular}{lcccc}
\hline & Overall & $\begin{array}{c}\text { Convenience } \\
\text { products }\end{array}$ & Clothes & $\begin{array}{c}\text { Domestic } \\
\text { appliances }\end{array}$ \\
\hline $\begin{array}{l}\text { Odd price represent a product with a } \\
\text { discount }\end{array}$ & 2.41 & 2.29 & 2.55 & 2.40 \\
\hline $\begin{array}{l}\text { Odd prices are used more for } \\
\text { cheaper products than expensive in } \\
\text { the same category of products }\end{array}$ & 2.46 & 2.54 & 2.47 & 2.37 \\
\hline $\begin{array}{l}\text { Products with odd price are worse } \\
\text { quality }\end{array}$ & 2.18 & 2.16 & 2.19 & 2.19 \\
\hline Odd price means getting change & 2.65 & 2.72 & 2.66 & 2.58 \\
\hline Odd price enables me to save money & 2.32 & 2.29 & 2.31 & 2.37 \\
\hline I associate odd price with cheating & 2.59 & 2.68 & 2.60 & 2.50 \\
\hline
\end{tabular}

Repeated measures ANOVA with the Greenhouse-Geisser correction determined that the means of statements differed statistically significantly $(F(3.607,743.012)=12.375$, $P<0.01)$. Post hoc tests using the Bonferroni correction revealed that the statement was statistically significantly different in the case of statements "Odd price means getting change", "I associate an odd price with cheating" and other statements $(P<0.05)$. Even though the respondents denied an association of odd price with getting change and cheating, these two statements had the highest evaluations. Another important finding was that respondents disagree with the statement "Products with odd prices are worse in quality" and the statement was statistically significantly different from other statements $(P<0.05)$. So, we can conclude that findings do not support hypotheses H1-H6. These findings contradict the data presented in the literature analysis. One of possible explanations was presented in the introduction. Most of the research related to odd prices was done in the USA and Western Europe or other developed countries. Lithuania might represent a case of a post-Soviet country that was influenced by the Soviet ideology.

In addition to that we can evaluate the perception of odd prices across different categories of products. Repeated measures ANOVA with the Greenhouse-Geisser correction determined that the mean of the statement "Odd price represents a product with a discount" differed statistically significantly between product categories $(F(1.706,351.445)$ $=8.997, P<0.01)$. Post hoc tests using the Bonferroni correction revealed that the statement was statistically significantly different (is less associated with a discount) in the case of convenience products than in the case of clothes (Mconv $=2.29 \mathrm{vs}$. Mcloth $=2.55, P<0.05$ ), and statistically significantly different (is less associated with a discount) in the case of domestic appliances than in the case of clothes (Mdomest $=2.40$ $v s$. Mcloth $=2.55, P<0.05)$. However, evaluation of statement "Odd prices represent a product with a discount" was not statistically significantly different in the case of convenience products and domestic appliances $(P=0.405)$. That shows the respondents do not expect to find odd prices on discounted convenience products, but they tend to associate odd prices with discounted shopping products. 
Next statement related to perception of odd prices was concerned with using odd prices for cheaper products. Repeated measures ANOVA with the Greenhouse-Geisser correction determined that the mean of the statement "Odd prices are used more for cheaper products than expensive ones in the same category of products" differed statistically significantly between product categories $(F(1.700,350.269)=4.570, P<0.05)$. Post hoc tests using the Bonferroni correction revealed that the statement was statistically significantly different (is more suitable for cheap products) in the case of convenience products than in the case of domestic appliances $($ Mconv $=2.54$ vs. Mdomest $=2.37$, $P<0.05)$. However, evaluation of the statement was not statistically significantly different between convenience products and clothes $(P=0.473)$, and between clothes and domestic appliances $(P=0.156)$. We can state that the respondents prefer to assign odd prices to cheaper products in the case of convenience products than in the case of shopping goods.

Other three statements did not differ depending on a type of product. Repeated measures ANOVA with the Greenhouse-Geisser correction determined that the mean of the statement "Products with odd prices are worse in quality" did not differ statistically significantly between product categories $(F(1.818,374.463)=0.251, P=0.757)$. The mean of the statement "Odd price means getting change" did not differ statistically significantly between product categories $(F(1.717,353.754)=3.385, P=0.051)$, either. Finally, repeated measures ANOVA with the Greenhouse-Geisser correction determined that the mean of the statement "Odd price enables me to save money" did not differ statistically significantly between product categories $(\mathrm{F}(1.819,374.722)=1.200, \mathrm{P}=0.300)$.

Repeated measures ANOVA with the Greenhouse-Geisser correction determined that the mean of the statement "I associate an odd price with cheating" differed statistically significantly between product categories $(F(1.647,339.228)=9.346, P<0.01)$. Post hoc tests using the Bonferroni correction revealed that the statement was statistically significantly different (respondents present a higher level of association of an odd price with cheating) in the case of convenience products than in the case of domestic appliances $($ Mconv $=2.68 v s$. Mdomest $=2.50, P<0.01)$ and statistically significantly different (respondents present a higher level of association of an odd price with cheating) in the case of clothes than in the case of domestic appliances (Mcloth $=2.60 v \mathrm{~s}$. Mdomest $=$ $2.50, P<0.05)$. However, evaluation of the statement "I associate odd price with cheating" was not statistically significantly different in the case of convenience products and in the case of clothes $(P=0.205)$.

Table 3. Suitability of odd price depending of price level

\begin{tabular}{ccc}
\hline & Mean & Std. deviation \\
\hline Less than $10 \mathrm{Lt}$ & 3.69 & 1.155 \\
\hline $10-100 \mathrm{Lt}$ & 3.29 & 1.067 \\
\hline $100-1000 \mathrm{Lt}$ & 2.50 & 1.083 \\
\hline $1000-10000 \mathrm{Lt}$ & 2.20 & 1.214 \\
\hline
\end{tabular}


Repeated measures ANOVA with the Greenhouse-Geisser correction determined that the mean "Odd price is suitable for a price ..." differed statistically significantly between all categories of a price $(F(1.630,261.894)=105.191, P<0.01)$ (see Table 3$)$. Post hoc tests using the Bonferroni correction revealed that the statement was statistically significantly different (respondents present a higher level of suitability) in the case of prices lower than 10 LTL compared with that of 10-100 LTL $($ M10 $=3.69$ vs. M100 = $3.29, P<0.01)$. That indicates respondents' expectation to see odd prices if a product costs less than 10 LTL. According to respondents, odd prices are still differs compared with the level of a price $100-1,000(\mathrm{M} 100=3.29 \mathrm{vs} . \mathrm{M} 1000=2.50, P<0.01)$. Finally, respondents noticed that the interval of a price between 1,000 and 10,000 LTL is the least suitable for odd prices, since it statistically significantly differs from a price level $100-1,000$ LTL $(\mathrm{M} 1000=2.50 v s . \mathrm{M} 10000=2.20, P<0.01)$. So we can conclude that H8 was supported.

Table 4. Suitability of odd price depending of price level

\begin{tabular}{lll}
\hline & Mean & Std. deviation \\
\hline I prefer a price 6,99, than 7,01 & 3.13 & 1.100 \\
\hline I prefer a price 69,99 than 70,11 & 2.75 & 1.053 \\
\hline I prefer a price 699,99 nei 700,11 & 2.75 & 1.124 \\
\hline
\end{tabular}

Repeated measures ANOVA with the Greenhouse-Geisser correction determined that the mean "I prefer a price ..." differed statistically significantly between the levels of the price $(F(1.717,36.853)=18,149, P<0.01)$. Post hoc tests using the Bonferroni correction revealed that the statement was statistically significantly different (odd prices were preferred more) in the case of 6.99 than in the case of 69.99 (M6.99 $=3.13 \mathrm{vs}$. M66.99 $=2.75, P<0.01$ ) and different (odd prices were preferred more) in the case of 6.99 than in the case of $699.99(\mathrm{M} 6.99=3.13$ vs. M699.99 = 2.75, $P<0.01)$. However, evaluation of the statement "I prefer the price ..." was not statistically significantly different in the cases of 69.99 and $699.99(P=1.000)$.

\section{Conclusions}

The respondents evaluated all statements below average, which means that they did not agree with the presented statements. These findings do not support the hypotheses H1-H6. The respondents stated that they did not associate an odd price either with a discount, with lower quality, with getting change, or with cheating. According to them, odd prices are used for cheaper products as well as for expensive ones in the same category of products, but these prices do not let save money. Our results differ from the findings of other studies in developed countries. Therefore we can conclude that a strong impact of the ideology of the planned economy and 15 years of usage of odd prices by retailers caused a different attitude of Lithuanian consumers towards odd prices.

The respondents did not associate odd prices with cheating, but the statement "I associate odd prices with cheating" had one of the highest evaluations. Therefore we can guess 
that respondents intuitively perceive odd prices as something negative. Moreover, the respondents showed a higher level of association of odd prices with cheating in the case of convenience products than in the case of domestic appliances. It is obvious, since convenience products are purchased every day and consumers have more experience with these products. By contrast, the respondents associated odd prices with discounted products in the case of shopping goods. Since consumers spend more time purchasing shopping goods than convenience goods they pay more attention to prices and situations when odd prices are used more often.

Even though Lithuanian consumers have a different attitude about odd prices, their behavioral experience fits the results of the research from developed countries. Respondents expected to find odd prices if the product was less than 10 LTL or 10-100 LTL, but higher prices were less suitable odd prices. Finally, the respondents showed their behavioral intentions related to odd prices. The participants noticed that they would prefer odd prices in the case of cheap products (6.99 or 7.01 LTL), but odd prices would not be preferable in the case of more expensive products (69.99 or 699.99 LTL). Thus, we can conclude that the behavioral component of attitude corresponds to the results of other research.

Several limitations of the research would be worth mentioning. First of all, demographic data of the respondents show that a big part of respondents evaluated their income as high or average. Since the perception of a price might be related with the respondents' income we received quite positive attitude toward odd prices. Moreover, the main part of the respondents was between 18 and 39 years old, which mainly represented the population of young consumers. Finally, the research was done during the recession of Lithuanian economics, which could have had impact on the results as well. Therefore it would be worth evaluating attitudes toward odd prices in other post-Soviet countries.

\section{References}

Alpert, M. I.; McGrath, J. E.; Alpert, J. I. 1984. Magic prices: an extension, in Proceedings of American Institute for Decision Sciences Western Region, 111-113.

Asamoah, E. S.; Chovancova, M. 2011. The influence of price endings on consumer behaviour: an application of the psychology of perception, Acta Universitatis Agriculturae et Silviculturae Mendeleianae Brunensis 7: 29-38. http://dx.doi.org/10.11118/actaun201159070029

Basu, K. 2006. Consumer cognition and pricing in the nines in oligopolistic markets, Journal of Economics \& Management Strategy 15(1): 125-141.

http://dx.doi.org/10.1111/j.1530-9134.2006.00094.x

Baumgartner, B.; Steiner, W. J. 2007. Are consumers heterogeneous in their preferences for odd and even prices? International Journal of Research in Marketing 24: 312-323.

http://dx.doi.org/10.1016/j.ijresmar.2007.05.003

Bizer, G. Y.; Schindler, R. M. 2005. Direct evidence of ending-digit drop-off in price information processing, Psychology \& Marketing 22(10): 771-783. http://dx.doi.org/10.1002/mar.20084

Boyes, W. J.; Lynch, A. K.; Mounts, W. S. 2007. Why odd pricing? Journal of Applied Social Psychology 37(5): 1130-1140. http://dx.doi.org/10.1111/j.1559-1816.2007.00203.x

Brenner, G. A.; Brenner, R. 1982. Memory and markets, or why are you paying $\$ 2.88$ for a widget, Journal of Business 55: 147-58. http://dx.doi.org/10.1086/296157 
Coulter, K. S. 2002. The influence of print advertisement organization on odd-ending price image effects, Journal of Product and Brand Management 11(5): 319-334.

http://dx.doi.org/10.1108/10610420210442193

Folkertsma, C. K. 2002. The Euro and psychological prices: simulations of the worst-case scenario, The Economist 150(1): 19-40.

Fortin, D.; Cleland, S.; Jenkins, A. 2008. Effects of advertised pricing on brand image for an on-line retailer, in Proceedings of the 2008 Conference of the American Academy of Advertising, 27-30 March, 2008, San Mateo, CA, USA, 263-275.

Gaston-Breton, C. 2011. Consumer preferences for 99-ending prices: the mediating role of price consciousness, Universidad Carlos III de Madrid, Business Economic Series 03, Working Paper 5.

Gendall, P.; Holdershaw, J.; Garland, R. 1997. The effect of odd pricing on demand, EuropeanJournal of Marketing 31(11-12): 799-813. http://dx.doi.org/10.1108/03090569710190541

Gueguen, N.; Legoherel, P. 2004. Numerical encoding and odd - ending prices. The effect of a contrast in discount perception, Journal of Marketing 38(1/2): 194-208.

http://dx.doi.org/10.1108/03090560410511186

Guido, G.; Peluso, A. 2004. Consumers' perception of odd - ending prices with the introduction of the Euro, Journal of Product \& Brand Management 13(3): 200-210.

http://dx.doi.org/10.1108/10610420410538096

Högl, S. 1988. The effects of simulated price changes on consumers in a retail environment price thresholds and price policy, in Esomar Congress Proceedings, 1998, Lisbon.

Holdershaw, J.; Gendall, P.; Garland, R. 1997. The widespread use of odd-pricing in the retail sector, Marketing Bulletin (8): 53-58.

Hooley, G.; Cox, T.; Fahy, J.; Shipley, D.; Jozsef, B.; Krzysztof, F.; Snoj, B. 2000. Market orientation in the transition economies of Central Europe: test of the Narver and Slater market orientation scales, Journal of Business Research 50(3): 273-285.

http://dx.doi.org/10.1016/S0148-2963(99)00105-8

Hornik, J.; Cherian, J.; Zakay, D. 1994. The influence of prototypic values on the validity of studies using time estimates, Journal of the Market Research Society 36: 145-147.

Hultsman, W.; Hultsman, J.; Black, D. 1989. Response peaks as a component of measurement error: assessment implications for self-reported data in leisure research, Journal of Leisure Research 21(4): 310-315.

Hunt, K.; Keaveney, S. 1994. A process model of the effects of price promotions on brand image, Psychology and Marketing 11(6): 511-532. http://dx.doi.org/10.1002/mar.4220110602

Kleinsasser, S.; Wagner, U. 2011. Price endings and tourism consumers' price perceptions, Journal of Retailing and Consumer Services 18(2011): 58-63.

http://dx.doi.org/10.1016/j.jretconser.2010.09.011

Liang, J.; Kanetkar, V. 2006. Price endings: magic and math, Journal of Product \& Brand Management 15(6): 377-385. http://dx.doi.org/10.1108/10610420610703702

Lambert, Z. V. 1975. Perceived prices as related to odd and even price endings, Journal of Retailing 51: 13-78.

Mace, S. 2012. The impact and determinants of nine-ending pricing in grocery retailing, Journal of Retailing 88(1): 115-130. http://dx.doi.org/10.1016/j.jretai.2011.07.002

Monroe, K. B. 1973. Buyers' subjective perceptions of price, Journal of Marketing Research 10(1): 70-80. http://dx.doi.org/10.2307/3149411

Nagle, T.; Holden, R. K. 1995. The strategy and tactics of pricing. 2nd ed. Englewood Cliffs, NJ: Prentice-Hall. 
Naipaul, S.; Parsa, H. G. 2001. Menu price endings that communicate value and quality, Cornell Hotel and Restaurant Administration Quarterly 42: 26-37.

http://dx.doi.org/10.1016/S0010-8804(01)90008-4

Ngobo, P. V.; Legohérel, P.; Gueguen, N. 2010. A cross-category investigation into the effects of nine-ending pricing on brand choice, Journal of Retailing and Consumer Services 17(5): 374-85. http://dx.doi.org/10.1016/j.jretconser.2010.03.018

Nguyen, A.; Heeler, R. M.; Taran, Z. 2007. High-low context cultures and price-ending practices, Journal of Product \& Brand Management 16(3): 206-214.

http://dx.doi.org/10.1108/10610420710751582

Quester, P.; Lim, A. L. 2003. Product involvement/brand loyalty: is there a link?, Journal of Product \& Brand Management 12(1): 22-38. http://dx.doi.org/10.1108/10610420310463117

Quigley, C. J.; Notarantonio, E. M. 1992. An exploratory investigation of perceptions of odd and even pricing, in V. L. Crittenden (Ed.). Developments in marketing science. Chestnut Hill, MA: Academy of Marketing Science, 306-309.

Rao, A. R.; Monroe, K. B. 1988. The moderating effect of prior knowledge on cue utilization in product evaluations, Journal of Consumer Research 15(September): 253-264.

http://dx.doi.org/10.1086/209162

Schindler, R. M. 1984. Consumer recognition of increases in odd and even prices, Advances in Consumer Research 11: 459-462.

Schindler, R. M.; Kibarian, T. M. 1993. Testing for perceptual underestimation of 9-ending prices, Advances in Consumer Research 20: 580-585.

Schindler, R. M. 1991. Symbolic meanings of a price ending, in R. H. Holman, M. R. Solomon (Eds.). Advances in consumer research, vol. 18. Provo, UT: Association for Consumer Research, 794-801.

Schindler, R. M.; Kibarian, T. M. 2001. Image communicated by the use of 99 endings in advertised prices, Journal of Advertising 30(4): 95-99.

http://dx.doi.org/10.1080/00913367.2001.10673654

Schindler, R. M.; Warren, L. S. 1988. Effect of odd pricing on choice of items from a menu, Advances in Consumer Research 15: 348-53.

Schindler, R. M.; Wiman, A. R. 1989. Effects of odd pricing on price recall, Journal of Business Research 19(3): 165-77. http://dx.doi.org/10.1016/0148-2963(89)90017-9

Schindler, R. M.; Kirby, P. N. 1997. Patterns of rightmost digits used in advertised prices: implications for nine-ending effects, Journal of Consumer Research 24(2): 192-201.

http://dx.doi.org/10.1086/209504

Schindler, R. M. 2009. Patterns of price endings used in US and Japanese price advertising, International Marketing Review 26(1): 17-29. http://dx.doi.org/10.1108/02651330910933186

Snieškienè, G. 2009. Išorinès aplinkos veiksnių poveikio eksporto kainodaros strategijai vertinimas [Evaluation of the effect of factors of external environment on the strategy of export pricing], Economics and Management 14: 968-975.

Stiving, M.; Winer, R. S. 1997. An empirical analysis of price endings with scanner data, Journal of Consumer Research 24(1): 57-67. http://dx.doi.org/10.1086/209493

Stiving, M. 2000. Price-endings: when price signals quality, Management Science 46(December): 1617-1629. http://dx.doi.org/10.1287/mnsc.46.12.1617.12078

Suri, R.; Anderson, A. E.; Kotlov, V. 2004. The use of 9-ending prices: contrasting the USA with Poland, European Journal of Marketing 38(1/2): 56-72.

http://dx.doi.org/10.1108/03090560410511122 
Thomas, M.; Morwitz, V. 2005. Penny wise and pound foolish: the left-digit effect in price cognition, Journal of Consumer Research 32(June): 54-56. http:://dx.doi.org/10.1086/429600

Usunier, J. C. 1996. Cultural aspects of international business negotiations, in P. N. Ghauri, J. C. Usunier (Eds.). International business negotiations. Pergamon, New York: 91-118.

Wagner, R.; Beinke, K. S. 2006. Identifying patterns of customer response to price endings, Journal of Product and Brand Management 15(5): 341-351. http://dx.doi.org/10.1108/10610420610685730

Vytautas DIKCIUS, Prof. Dr, is a Full Professor at the International Business School at Vilnius University, in Lithuania. He studied Business and Economics at the Vilnius University. He has published over 20 articles in both national and international academic journals and two books on marketing research. Research interests: consumer behavior, sensory marketing, pricing, corporate social responsibility.

Kristina KATKUVIENE has been working in the manufacturing and service rendering company in Lithuania for more than ten years and for the recent five years she has been managing the Marketing Department. She graduated International Marketing and Trade studies and was awarded a Master's Degree in Management and Business Administration. She is the co-author of two researches (Importance of Packaging in Different Segments of the Market and Actions Reducing the Resistance to Organizational Changes in Advertising Companies). 